\title{
DIETARY ANALYSIS OF THREE SPECIES OF THE GENUS ANOLIS (SAURIA: DACTYLOIDAE) IN “LOS TUXTLAS," VERACRUZ, MEXICO
}

\author{
ANÁLISIS DIETÉTICO DE TRES ESPECIES DEL GÉNERO DE ANOLIS(SAURIA: DACTYLOIDAE) \\ EN "LOS TUXTLAS", VERACRUZ, MÉXICO

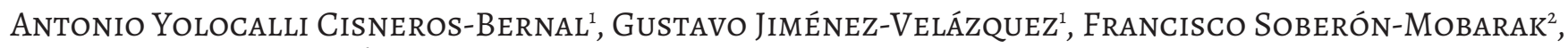 \\ OSCAR FlORES-VILLELA ${ }^{1 *}$, AND RICHARD C. VOGT ${ }^{3}$ \\ ${ }^{1}$ Museo de Zoología Facultad de Ciencias, Universidad Nacional Autónoma de México, Ciudad Universitaria, CDMX, 04510. \\ ${ }^{2}$ Xavier Sorondo 210, CDMX 03520. \\ ${ }^{3}$ Instituto Nacional de Pesquisas da Amazônia (INPA), Coordenaçâo de Pesquisa em Biologia Aquática, Av. André Araújo, 2936, Bairro Petrópolis, \\ Caixa Postal 478, 69083-970 Manaus, Amazonas, Brazil. \\ "Correspondence author: ofvg@unam.mx
}

Abstract.- Anoles have been studied by researchers to a greater extent than any other group of lizards. Their high diversity has led them to colonize a variety of niches, making them an ideal model group for evaluating ecological hypotheses such as dietary niche overlap. This work analyzes the stomach contents of 73 individuals from three species of the genus Anolis: A. barkeri (34), A. sericeus (17), and A. tropidonotus (22) occurring in the vicinity of Los Tuxtlas, Veracruz. Analyses performed included Shannon's index in its $\log$ form to calculate dietary diversity, the Jaccard index to estimate the dissimilarity of the species' diets, and Schoener's index to measure dietary overlap. The results suggest that A. barkeri (10.08) hast the most generalist diet, followed by A. sericeus (8.75) and A. tropidonotus (5.78). Schoener's index showed a considerable amount of diet overlap between A. barkeri and A. sericeus (0.76). We conclude that the three focal species show a generalist feeding behavior in times of abundant prey, such as the rainy season in which this study was conducted. This may lead to a reduction of interspecific competition explaining why we did not observe dietary niche displacement between these three sympatric species of Anolis.

Keywords.- Anolis barkeri, Anolis sericeus, Anolis tropidonotus, tropical rainforest, feeding habits.

Resumen.- Los Anolinos son un grupo de lagartijas que mayor atención ha recibido por parte de investigadores. Tienen una alta diversidad, lo que les ha permitido colonizar diferentes nichos, convirtiéndolos en modelos ideales para evaluar hipótesis ecológicas como el sobrelapamiento de nicho dietético. En este trabajo se evaluaron los contenidos estomacales de 73 individuos de tres especies del genero Anolis: A. barkeri (34), A. sericeus (17) y A. tropidonotus (22) de la región de Los Tuxtlas, Veracruz. Se hicieron análisis utilizando el índice de Shannon en su forma logarítmica para calcular diversidad dietética; el índice de Jaccard para estimar la disimilitud de las dietas y el índice de Schoener para conocer el sobrelapamiento de dietas. Los resultados sugieren que A. barkeri (10.08) es la especie más generalista, seguida por A. sericeus (8.75) y A. tropidonotus (5.78). El índice de de Schoener muestra un sobrelapamiento de dietas considerable entre A. barkeri y A. sericeus (0.76). Se concluye que los Anolis de este estudio, presentan un comportamiento generalista en situaciones de abundancia de presas, como es la temporada de lluvias. Lo anterior puede reducir la competencia por lo que no se observa un desplazamiento de nicho dietético entre estas tres especies simpátricas de Anolis.

Palabras clave.- Anolis barkeri, Anolis sericeus, Anolis tropidonotus, selva alta perennifolia, hábitos alimenticios. 


\section{INTRODUCTION}

The genus Anolis is a group of lizards that has been used extensively in ecological and evolutionary studies given their large diversity (Losos, 2009). The genus contains approximately 400 species (Poe et al., 2017), with a distribution extending from southeastern United States, through Mexico, and into parts of South America, as well as the Caribbean islands (Losos, 2009). The majority of ecological and evolutionary studies on Anolis have focused on the island populations, for which the interspecific interactions and trophic levels have had important evolutionary consequences (Losos, 2009). Similarly, data on the dietary composition of island Anolis species have been widely reported in the literature (Wolcott, 1923; Schoener et al., 1968; Lister, 1981; Reagan, 1986; Dial \& Roughgarden, 2004; Herrel et al., 2004), while the diets of mainland species have been less studied (Andrews, 1971; Sexton, 1972; Fitch, 1972, 1975; Lister \& Garcia-Aguayo, 1992; Seliceo-Cantero \& Garcia, 2015). Sympatric Anolis species are thought to exhibit different diets in order to partition resources when living in sympatry, leading to trophic niche partitioning (Losos, 2009). However, few studies have tested this hypothesis in mainland Anolis species.

This work presents the results of a dietary analysis of three sympatric species of Anolis found on the biosphere reserve "Los Tuxtlas" in Veracruz, Mexico. The focal species include A. barkeri, which occupies a semiaquatic habitat on rocks and debris near streams and rivers (Birt et al., 2001); A. sericeus, which tends to be found in trees and bushes of more arid areas (Henderson \& Fitch, 1975); and A. tropidonotus, a strictly terrestrial lizard commonly found in the leaf litter (Henderson \& Fitch, 1975).

\section{MATERIAL AND METHODS}

Organisms for this study were collected by RCV and OFV, at the Tropical Biological Station "Los Tuxtlas", UNAM during the rainy season (May to November). The stomach contents of 73 individuals from the three focal species were analyzed: A. barkeri (34), A. sericeus (17), and A. tropidonotus (22). Stomach items were identified to order-level, and the total volume of stomach contents, as well as each individual item, was calculated using volumetric displacement in a test tube. The frequency of the presence of prey items was calculated per Anolis species, effectively homogenizing the diet for each species and avoiding count bias for parts of prey in an individual's stomach.

The resulting frequency table was inputted into the "vegan" package (Oksanen et al., 2015) in $\mathrm{R}$ ( $\mathrm{R}$ Core Team, 2013) to calculate Shannon's Index in its log form (effective numbers) in order to compare the dietary diversity between each species (Moreno et al., 2010). Furthermore, Jaccard's dissimilarity index
(1 - Jaccard's Index) was calculated to understand which species are least similar in respect to the incidences of prey that they consumed. Finally, values of trophic niche overlap between species were calculated using Schoener's Index implemented in the package "spaa" (Zhang, 2013).

\section{RESULTS}

A total of 14 distinct prey items were found in the stomach contents of the observed lizards. The results show that A. barkeri had the most number of food items in their diet, followed by $A$. sericeus, and lastly A. tropidonotus (Table 1). The effective number of species (1D) is shown in Table 2. Anolis barkeri was found to have the most diverse diet, followed by A. sericeus, and lastly A. tropidonotus (Table 2).

The results also show that the largest trophic niche overlap occurs between the pair A. barkeri and A. sericeus, followed by the pair A. barkeri and A. tropidonotus. The least amount of trophic niche overlap was found between A. sericeus and A. tropidonotus (Table 3).

Lastly, the results of the Jaccard's Index show that A. sericeus and A. tropidonotus had the most similar diet, followed by A. sericeus

Table 1. Frequency of prey items found in the three focal species.

Tabla 1. Porcentajes de ítems de presa encontrados en cada una de las tres especies.

\begin{tabular}{cccc}
\hline Items/Species & A. barkeri & A. sericeus & A. tropidonotus \\
\hline Arachnids & 61.76 & 50.00 & 47.05 \\
Coleopterans & 4.14 & 43.75 & 11.76 \\
Dipterids & 23.53 & 56.25 & 23.52 \\
Hemipterans & 14.70 & 25.00 & 11.76 \\
Homopterans & 8.82 & 6.25 & 5.88 \\
Hymenopterans & 38.23 & 31.25 & 47.05 \\
Lepidopterans & 2.94 & & \\
Orthopterans & 17.64 & 31.25 & 5.88 \\
Larvae & 35.29 & 31.25 & \\
Plant material & 5.88 & 12.50 & \\
Crustaceans & 14.70 & 18.75 & 5.88 \\
Odonatans & 23.53 & & \\
Collembola & 5.88 & & \\
\hline
\end{tabular}


Table 2. Dietary diversity of the three focal species, represented by their effective numbers.

Tabla 2. Diversidad trófica de las tres especies evaluadas, representadas por los números efectivos.

\begin{tabular}{cc}
\hline Species & Effective numbers \\
\hline A. barkeri & 10.08 \\
A. sericeus & 8.75 \\
A. tropidonotus & 5.78 \\
\hline
\end{tabular}

and A. barkeri. The least similar diet was found between A. barkeri and A. tropidonotus (Table 4).

\section{DISCUSSION}

The results of this study support the findings from Losos et al. (2009) in relation to the generalist dietary components observed in Anolis. These lizards tend to adopt a generalist diet when a prey item is found abundantly and can be easily captured. Regarding the three Anolis species studied in this work, arachnids were the most abundant prey item.

Our data revealed that $A$. barkeri is the most generalist of the three species, corroborating the findings of Birt et al. (2001). Second in prey diversity was A. sericeus, nested between the generalist $A$. barkeri and the specialist A. tropidonotus. These results suggest that the semiaquatic habitats of $A$. barkeri provide a larger diversity of foraging grounds and access to a variety of different prey (Birt et al., 2001). When Schoener's values of overlap were compared, A. barkeri and A. sericeus were found to have the highest value (0.76), indicating that although $A$. barkeri has the most expansive diet, the species shows preference for the same terrestrial prey as A. sericeus, and not for prey found in aquatic environments. This could be an artifact of the season in which the lizards were collected (rainy season, between May and November), given that some tropical invertebrates reach their highest abundance during the rainy season (Didham \& Springate, 2003; Wolda, 1989; Santana et al., 2015). Although their diets overlapped, partitioning of dietary components between these two species was not observed, likely due to the high prevalence of prey items.

The results of the dietary components dissimilarity analysis (Jaccard Index) suggest that these three sympatric species of Anolis are not competing for food resources, as suggested by Losos (2009). It is likely that an abundant availability of prey items is related with a high diet similarity between species. Even though they display some similarities, it seems that variation in existing habitat and the opportunistic condition of feeding
Table 3. Values of trophic niche overlap (Schoener's Index) between the three focal species of Anolis.

Tabla 3. Valores de superposición de nicho trófico (Índice de Schoener) entre las tres especies de Anolis.

\begin{tabular}{ccc}
\hline & A. barkeri & A. sericeus \\
\hline A. sericeus & 0.76 & \\
A. tropidonotus & 0.66 & 0.65 \\
\hline
\end{tabular}

behavior lead to the avoidance of competition for food between these three species.

The results should be considered as preliminary given the small sample size and the limited seasonality covered. Several studies have found that the diet of Anolis species varies intraand interspecifically between different habitats of the same locality (i.e. A. stratulus Reagan, 1986; A. conspersus Schoener, 1967; A. sagrei, A. distichus, A. carolinensis, and A. angusticeps Schoener, 1968; A. opalicnus Floyd \& Jensen, 1983; and A. aeneus Stamps et al., 1997). Another limiting aspect of this study was the classification of prey items to their order level, which may introduce bias into the analyses, particularly in the conclusions of dietary similarities (Greene \& Jaksić, 1983). Further studies should include a larger sample size, sampling throughout a broader temporal scale, higher taxonomic resolution of dietary components, and an evaluation of available prey at each site.

Table 4. Values of Jaccard Index between the three focal Anolis species.

Tabla 4. Índice de incidencia de Jaccard entre las tres especies de Anolis analizadas.

\begin{tabular}{ccc}
\hline & A. barkeri & A. sericeus \\
\hline A. sericeus & 0.76 & \\
A. tropidonotus & 0.61 & 0.8 \\
\hline
\end{tabular}

Acknowledgements. - This work was part of a bachelor's thesis of FSM, we want to thank the committee that reviewed the thesis Fausto Méndez de la Cruz, Moises Armando Luis Martínez, Jesús Serrano and Adrian Quijada Mascareñas. We also thank José Quintero and Rolando Mendoza Trejo for their support. Brett O. Butler translated this paper to English; we thank him for his help. AYCB wish to thank the support of Sistema Nacional de Investigadores (SNI) for economic support.

\section{CITED LITERATURE}

Andrews, R.M. 1971. Structural habitat and time budget of a tropical 
Anolis lizard. Ecology 52:262-270.

Bird, R.A., R. Powell \& B.D. Greene. 2001. Natural History of Anolis barkeri: A Semiaquatic Lizard from Southern México. Journal of Herpetology 1:161-166.

Dial, R. \& J. Roughgarden. 2004. Physical transport, heterogeneity, and interactions involving canopy anoles. Pp. 270-296. In M. Lowman \& B. Rinker (Eds.), Forest Canopies. 2nd Ed. Academic Press: New York, New York, USA.

Didham, R.K. \& N.D. Springate. 2003. Determinants of temporal variation in community structure. Pp. 28-39. In Basset, Y., V. Novotny, S.E. Miller \& R.L. Kitching (Eds.), Arthropods of tropical forests. Spatio-temporal dynamics and resource use in the canopy. Cambridge University Press, Cambridge, UK.

Fitch, H.S. 1972. Ecology of Anolis tropidolepis in Costa Rican cloud forest. Herpetologica 28:10-21.

Fitch, H.S. 1975. Sympatry and interrelationships in Costa Rican anoles. Occasional Papers of the Museum of Natural History, the University of Kansas, Lawrence, Kansas 40:1-60.

Floyd, H.G. \& T.A. Jenssen. 1983. Food habits of the Jamaican lizard, Anolis opalinus: Resource partitioning and seasonal effects examined. Copeia 1983:319-331.

Greene, H.W. \& F.M. Jaksić. 1983. Food-niche relationships among sympatric predators: Effects of level of prey identification. Oikos 40:151-154.

Henderson, R.W. \& H.S. Fitch. 1975. A comparative study of the structural and climatic habitats of Anolis sericeus (Reptilia: Iguanidae) and its syntopic congeners at four localities in southern Mexico. Herpetologica 31:459-471.

Herrel, A., B. Vannhooydonck \& R. Joachim. 2004. Frugivory in polychrotid lizard: effects of body size. Oecology 140:160-168.

Lister, B.C. 1981. Seasonal niche relationships of rain forest anoles. Ecology 62:1548-1560.

Lister, B.C. \& A. Garcia Aguayo. 1992. Seasonality, predation, and the behavior of a tropical mainland anole. Journal of Animal Ecology 61:717-733.

Losos, J.B. 2009. Lizards in an evolutionary tree. Ecology and adaptive radiation of anoles. University of California Press.
Berkeley, California USA.

Moreno, C.E., F. Barragán, E. Pineda \& N.P. Pavón. 2011. Reanálisis de la diversidad alfa: alternativas para interpretar y comparar información sobre comunidades ecológicas. Revista Mexicana de Biodiversidad 8:1249-1261.

Oksanen, J., F.G. Blanchet, R. Kindt, P. Legendre, P.R. Minchin, R.B. O'Hara, G.L. Simpson, P. Solymos, M.H.H. Stevens, \& H. Wagner. 2015. Vegan: Community Ecology Package. R package version 2.3-2. http://CRAN.R-project.org/package=vegan. [Visited October, 2017].

Poe, S., A. Nieto-Montes de Oca, O. Torres-Carvagal, K. De Queiroz, J.A. Velasco, B. Truett, L.N. Gray, M.J. Ryan, G. Köhler, F. AyalaVarela \& I. Latella. 2017. A phylogenetic, Biogeographic, and Taxonomic study of all Extant Species of Anolis (Squamata; Iguanidae). Systematic Biology 66:663-697.

Reagan, D.P. 1986. Foraging behavior of Anolis stratulus in a Puerto Rican rain forest. Biotropica 18:157-160.

R Core Team. 2013. R: A language and environment for statistical computing. R Foundation for Statistical Computing, Vienna, Austria. URL http://www.R-project.org/. [Accessed October, 2017].

Santana, H.S., L.C.F. Silva, C.L. Pereira, J. Simiao-Ferrerira \& R Angelini. 2015. The rainy season increases the abundance and richness of the aquatic insect community in al Neotropical reservoir. Brazilian Journal of Biology 75:144-151.

Seliceo-Cantero, H.H. \& A. García. 2015. Actividad y uso del hábitat de una población insular y una continental de lagartijas Anolis nebulosus (Squamata: Polychrotidae) en un ambiente estacional. Revista Mexicana de Biodiversidad 86:406-411.

Sexton, O.J., J. Bauman \& E. Ortleb. 1972. Seasonal food habits of Anolis limifrons. Ecology 53:182-186.

Schoener, T.W.1967. The ecological significance of sexual dimorphism in size of the lizard Anolis conspersus. Science 155:474-478.

Schoener, T.W. 1968. The Anolis lizards of Bimini: Resource partitioning in a complex fauna. Ecology 49:704-726.

Schoener, T.W. \& G.C. Gorman. 1968. Some niche differences in three Lesser Antillean lizards of the genus Anolis. Ecology 49:819830. 
Stamps, J.A., J.B. Losos \& R.M. Andrews. 1997. A comparative study of population density and sexual size dimorphism in lizards. American Naturalist 149:64-90.

Wolcott, G.N. 1923. The food of Porto Rican lizards. Journal of the Department of Agriculture of Porto Rico 7:5-43.
Wolda, H. 1989. Seasonal cues in tropical organisms. Rainfall? Not necessarily!. Oecologia 80:437-442.

Zhang, J. 2013. spaa: Species Association Analysis. R package version 0.2.1 http://CRAN.R-project.org/package=spaa. [Accessed October, 2017]. 